REVIEW

\title{
Dehydroepiandrosterone, obesity and cardiovascular disease risk: a review of human studies
}

\author{
André Tchernof ${ }^{1,2}$ and Fernand Labrie ${ }^{1}$ \\ ${ }^{1}$ Molecular Endocrinology and Oncology Research Center, ${ }^{2}$ Department of Food Sciences and Nutrition, Laval University Hospital Research Center \\ (CHUL Research Center) and Laval University, Quebec G1V 4G2, Canada
}

(Correspondence should be addressed to A Tchernof, Molecular Endocrinology and Oncology Research Center, CHUL Research Center, 2705 Laurier Blvd. (T3-67), Quebec, Quebec G1V 4G2, Canada; Email: andre.tchernof@crchul.ulaval.ca)

\begin{abstract}
The age-related decline in serum dehydroepiandrosterone (DHEA) and its sulfated ester (DHEA-S) has suggested that a relative deficiency of these steroids may be causally related to the development of chronic diseases generally associated with aging, including insulin resistance, obesity, cardiovascular disease, cancer, reductions of the immune defense, depression and a general deterioration in the sensation of well-being. The numerous studies which have focused on the link between DHEA and cardiovascular disease have generally been inconsistent, generating much debate and controversy on this issue. The present article is an analysis of studies on the relationship between endogenous DHEA or DHEA-S, obesity and cardiovascular disease risk, as well as DHEA treatment studies. Elevated plasma levels of free DHEA are associated with reduced obesity in both men and women, and with smaller abdominal body fat accumulations in men. However, contradictory results have been reported regarding the relationships between the sulfate ester DHEA-S and adiposity. Age differences in the populations studied may have been a confounding factor in these associations. On the other hand, DHEA-S level is not a predictor of cardiovascular disease endpoints in women, and appears to be a relatively weak one in men. DHEA intervention studies suggest that the effects of DHEA on serum lipids are, at best, modest or non-significant. The uncertainty as to whether endogenous and exogenous DHEA should be considered cardioprotective is related to discrepancies in the literature on this topic. Several studies may have been plagued by methodological problems such as low power, unreliable analytical methods, confounding factors or other differences in the populations studied. As a consequence, the original reports demonstrating dramatic effects of either endogenous or exogenous DHEA on cardiovascular disease risk have never been replicated. We propose that the effects of DHEA on cardiovascular disease risk (either favorable or unfavorable) should be considered to be much more modest than previously believed.
\end{abstract}

European Journal of Endocrinology 151 1-14

\section{Introduction}

Humans and other primates are unique in having elevated circulating levels of dehydroepiandrosterone (DHEA) and its sulfated ester (DHEA-S). In fact, in humans, DHEA-S concentration is 100- to 500-fold higher than that of testosterone and 1000 to 10000 times greater than that of estradiol. DHEA and DHEA$\mathrm{S}$, however, do not possess intrinsic estrogenic or androgenic activity. These inactive precursor steroids are converted into active androgens and estrogens in peripheral target tissues (1), a process that depends on the specific expression of the steroidogenic enzymes in each of these tissues, thus allowing humans and other primates to regulate locally the amounts of active steroids on a cellular basis. This newly identified mode of hormonal synthesis and action, called intracrinology, is complementary to the well-known endocrine and paracrine/autocrine modes of hormone action $(1,2)$.
The marked age-related decline in serum DHEA and DHEA-S $(3,4)$ has suggested that a relative deficiency of these steroids may be causally related to the development of a series of diseases generally associated with aging. Postulated consequences of low DHEA include insulin resistance (5), obesity $(6,7)$, cardiovascular disease (8), cancer (9), reduction of the immune defense (10), and psychosocial problems such as depression and a general deterioration in the sensation of wellbeing (11). The numerous studies which have focused on the link between DHEA and cardiovascular disease have generally been inconsistent, generating much debate and controversy on this issue (12-14). The present article is complementary to recent reviews focusing more generally on androgens and cardiovascular disease (15-17), and summarizes the information available in the literature on the relationship between endogenous DHEA or DHEA-S levels, obesity, body fat distribution and cardiovascular disease risk. The observations 
made from DHEA treatment on these variables are also summarized.

\section{Endogenous DHEA and DHEA-S}

\section{Obesity and body fat distribution}

Obesity is well recognized to be associated with higher morbidity and mortality (18) through its association with hypertension and an increased risk of type 2 diabetes and cardiovascular disease (19-22). Although the association between obesity and cardiovascular morbidity and mortality is of low magnitude compared with the impact of other well-known risk factors for cardiovascular events such as smoking, dyslipidemia and hypertension (22-25), the continuing increase in this condition's prevalence and its epidemic proportions in North America have reinforced the need for research in this field $(26,27)$. This notion has been further emphasized by recent data from the Framingham heart study (28), which showed a graded increase in the risk of heart failure across categories of body mass index (BMI) values. A growing body of evidence suggests that metabolic complications associated with obesity may be mediated to a large extent by differences in body fat distribution $(29,30)$. In this regard, the accumulation of fat in the abdominal region has been associated with an increased risk of developing cardiovascular disease and related mortality (31-38). Most studies have relied on the waist-to-hip ratio (WHR) to estimate the accumulation of adipose tissue in the abdominal region (39), while other investigators have used computed tomography to measure adipose tissue located in the abdominal cavity separately from the subcutaneous adipose tissue depot (or visceral adipose tissue) (40-42). Using imaging methods, studies have shown that abdominal, and especially visceral or intra-abdominal obesity, in both men and women, is closely associated with a dyslipidemic state which includes hypertriglyceridemia, hypo- $\alpha$ lipoproteinemia, elevated apolipoprotein B, a greater proportion of small, dense low-density lipoprotein (LDL) particles and an increased LDL-cholesterol to high-density lipoprotein (HDL)-cholesterol ratio (43-48). This condition is also associated with hyperinsulinemia, insulin resistance $(46,49-51)$ and, most importantly, an increased 5 -year risk of death (38).

As summarized in Table 1, several cross-sectional studies have examined the relationship between overweight, obesity and plasma levels of DHEA and DHEA-S. In both men and women, the majority of studies found a statistically significant negative correlation between plasma free DHEA levels and measures of total adiposity (52-57). Such data suggest that higher circulating DHEA is associated with lower body fat accumulation. Two studies out of six used more precise measures, such as body fat mass and percent body fat measured by hydrostatic weighing and confirmed these findings $(56,57)$. These correlations were found in both pre- and postmenopausal women (52-54), as well as Caucasian men of various ages (55-57). The relationship between plasma levels of the sulfate ester DHEA-S and measures of obesity is less consistent. Indeed, in eight studies performed in pre- or postmenopausal women, with samples including from 28 to 659 subjects, plasma DHEA-S levels were not significantly related to BMI or percent body fat, with the exception of one study (58) reporting a positive correlation between DHEA-S and BMI. The other studies only reported statistically non-significant trends (Table 1). In men, the magnitude and direction of the association between DHEA-S and obesity is also equivocal. Seven studies found a significant association between plasma DHEA-S and measures of obesity (5561 ), two studies found that DHEA-S was negatively associated with measures of obesity $(57,59)$, whereas five studies found the opposite $(55,56,58,60)$. A number of studies also found no significant association $(62-67)$.

Studies examining the associations between measures of body fat distribution and plasma DHEA or DHEA-S levels are summarized in Table 2. In women, none of the studies found a statistically significant association between plasma DHEA and the WHR. In men, all three studies where DHEA was measured found a significant negative association between DHEA levels and measures of abdominal fat distribution (55-57), thus suggesting that low circulating DHEA is associated with a more central distribution of adipose tissue. Two studies $(56,57)$ have examined the correlation between computed tomography measures of visceral adipose tissue area and plasma DHEA. These studies also reported a negative correlation, suggesting that low DHEA levels are associated with greater accumulation of fat within the abdominal cavity (Table 2). Again, the association between plasma DHEA-S and body fat distribution measures is less consistent. In women, two studies reported a negative association $(68,69)$, whereas two studies reported a positive association between the WHR and plasma DHEA-S (52, 70). Similar results were found in men, where three studies reported a negative association between plasma DHEA-S and a central accumulation of body fat $(55,56)$ and two other studies reported the opposite $(57,59)$. The association between computed tomography-measured visceral adipose tissue areas and DHEA-S was negative in one study (56) and positive in the other (57).

The reasons for these discrepancies are unclear at the present time. However, differences do not seem to be explained by sample size, ethnicity or the methodology used in the measurement of either body fatness or DHEA-S. Some of the studies were performed in non-smokers, thus suggesting that smoking status, which has been associated with alterations in DHEA and DHEA-S dynamics $(71,72)$, is not involved. It 
Table 1 Correlation coefficients between circulating DHEA or DHEA-S levels and measures of total adiposity.

\begin{tabular}{|c|c|c|c|c|}
\hline Studies & Measurement & DHEA & DHEA-S & Population \\
\hline \multicolumn{5}{|l|}{ Women } \\
\hline Vettor et al. (62) & BMI & ns & ns & 65 premenopausal \\
\hline Ravaglia et al. (59) & BMI & nd & ns & 39 older \\
\hline Maccario et al. (151) & BMI & nd & ns & 217 obese pre/postmenopausal \\
\hline Evans et al. (73) & \%IBW & nd & -0.22 & 80 premenopausal \\
\hline de Pergola et al. (68) & BMI & nd & -0.31 & 40 premenopausal \\
\hline Ivandic et al. (74) & BMI & nd & -0.45 & 70 premenopausal \\
\hline Haffner et al. (93) & BMI & nd & +0.10 & 253 postmenopausal \\
\hline Williams et al. (70) & $\begin{array}{l}\text { BMI } \\
\% \text { fat }\end{array}$ & $\begin{array}{l}\text { nd } \\
\text { nd }\end{array}$ & $\begin{array}{l}+0.15 \\
+0.14\end{array}$ & 96 premenopausal \\
\hline Abbassi et al. (58) & $\begin{array}{c}\text { BMI } \\
\text { Body fat mass } \\
\% \text { fat }\end{array}$ & $\begin{array}{l}\text { nd } \\
\text { nd } \\
\text { nd }\end{array}$ & $\begin{array}{l}+0.24^{\star} \\
+0.11 \\
+0.09\end{array}$ & 118 postmenopausal \\
\hline de Pergola et al. (53) & BMI & $-0.57^{\star}$ & +0.17 & 28 premenopausal \\
\hline Barrett-Connor \& Ferrara (52) & BMI & $-0.09 *$ & -0.06 & 659 postmenopausal \\
\hline de Pergola et al. (54) & BMI & $-0.90^{*}$ & nd & 13 premenopausal \\
\hline \multicolumn{5}{|l|}{ Men } \\
\hline Vettor et al. (62) & $\mathrm{BMI}$ & ns & ns & 46 \\
\hline Herranz et al. (63) & BMI & nd & -0.24 & 34 \\
\hline Haffner et al. (64-66) & BMI & nd & -0.13 & 178 Mexican-American/non-Hispanic whites \\
\hline Haffner et al. (67) & BMI & nd & +0.03 & 87 Finnish \\
\hline Ravaglia et al. (59) & BMI & nd & $+0.41^{*}$ & 36 older \\
\hline Vermeulen et al. (60) & BMI & +0.09 & $-0.28^{*}$ & 250 \\
\hline Field et al. (55) & BMI & $-0.13^{*}$ & $-0.09^{*}$ & 1241 \\
\hline \multirow[t]{3}{*}{ Abbassi et al. (58) } & BMI & nd & -0.15 & 144 older \\
\hline & Body fat mass & nd & $-0.27^{*}$ & \\
\hline & $\%$ fat & nd & $-0.30 *$ & \\
\hline \multirow[t]{3}{*}{ Couillard et al. (56) } & BMI & $-0.17^{*}$ & $-0.17^{*}$ & 217 \\
\hline & Body fat mass & $-0.25^{\star}$ & $-0.28^{*}$ & \\
\hline & $\%$ fat & $-0.20^{*}$ & $-0.23^{*}$ & \\
\hline Pritchard et al. (61) & Body fat mass & nd & $-0.46^{\star}$ & 12 pairs of male twins \\
\hline \multirow[t]{3}{*}{ Tchernof et al. (57) } & BMI & $-0.42^{*}$ & $+0.52^{*} \dagger$ & 80 \\
\hline & Body fat mass & $-0.38^{*}$ & $+0.48^{*} \dagger$ & \\
\hline & $\%$ fat & $-0.35^{\star}$ & $+0.44^{*} \dagger$ & \\
\hline
\end{tabular}

* Statistically significant association; nd, not determined; ns, non-significant correlation coefficient not provided in the paper. tnot provided in the original paper; \%IBW, percent ideal body weight determined from the midpoint for medium frame using tables from the Metropolitan Life Insurance Co.

can be hypothesized that the age-related decline in DHEA-S concentrations $(3,4)$ may have been a significant confounding factor in these associations, given that adiposity increases with age, while DHEA-S decreases. It is important to indicate that most of the associations presented in Tables 1 and 2 were not statistically adjusted for age $(54-59,62,67-69,73,74)$. In the study by Abbassi et al. (58), the association between DHEA-S and age was non-significant in women, which suggests that the positive association between BMI and DHEA-S was presumably independent of age in that study. Moreover, statistical adjustment for age did not abolish the negative association found in males between DHEA-S and body fat mass or percent body fat (58). Adjustment for age led to a non-significant correlation between DHEA-S and BMI in the women studied by Barrett-Connor \& Ferrara (52). On the other hand, statistical adjustment for age eliminated the negative association between total body fatness and DHEA-S in the study by Couillard et al. (56, C. Couillard, personal communication), whereas the positive association was not affected by such adjustment in our study (57). Non-significant associations between DHEA-S and measures of abdominal fat were reported in two studies after adjustment for age, or age and BMI $(53,63)$ and a significant, positive, age-independent association was found in women in two studies $(52,70)$. Thus, differences in the age of subjects may have represented an important confounding factor in the study of the relationships between obesity, body fat distribution and endogenous DHEA-S.

The mechanisms linking obesity, body fat distribution and serum DHEA or DHEA-S have not been fully elucidated, although several possibilities have been raised. Gordon et al. (75) observed that cell conversion to mature adipocytes is impeded in the presence of DHEA, whereas DHEA-S exhibited a minor inhibitory effect on glucose-6-phosphate dehydrogenase activity (75). The role of DHEA as precursor for active androgens and estrogens may also play a role in the relationship between obesity, body fat distribution and circulating DHEA. Steroids are lipophilic compounds which are highly soluble in adipose tissue $(76,77)$. Moreover, adipose tissue expresses the several steroid-converting enzymes necessary for local synthesis of active androgens/estrogens from inactive precursors such as DHEA 
Table 2 Correlation coefficients between circulating DHEA or DHEA-S levels and measures of body fat distribution.

\begin{tabular}{|c|c|c|c|c|}
\hline Studies & Measurement & DHEA & DHEA-S & Population \\
\hline \multicolumn{5}{|l|}{ Women } \\
\hline Maccario et al. (151) & WHR & nd & ns & 217 obese pre/postmenopausal \\
\hline Evans et al. (73) & WHR & nd & -0.06 & 80 premenopausal \\
\hline \multirow[t]{2}{*}{ Williams et al. (70) } & WHR & nd & -0.02 & 96 premenopausal \\
\hline & $\%$ trunk fat & nd & $+0.28^{*}$ & \\
\hline de Pergola et al. (68) & WHR & nd & $-0.38^{*}$ & 40 premenopausal \\
\hline \multirow[t]{2}{*}{ De Simone et al. (69) } & WHR & nd & $-0.69 *$ & 29 massively obese adolescents \\
\hline & Visceral AT & nd & $-0.94^{*}$ & \\
\hline Abbassi et al. (58) & WHR & nd & -0.18 & 118 postmenopausal \\
\hline Ivandic et al. (74) & WHR & nd & -0.44 & 70 premenopausal \\
\hline Ravaglia et al. (59) & WHR & nd & ns & 39 older \\
\hline Barrett-Connor \& Ferrara (52) & WHR & +0.06 & $+0.08^{*}$ & 659 postmenopausal \\
\hline de Pergola et al. (53) & WHR & -0.09 & +0.28 & 28 premenopausal \\
\hline de Pergola et al. (54) & WHR & +0.03 & nd & 13 premenopausal \\
\hline \multicolumn{5}{|l|}{ Men } \\
\hline Pritchard et al. (61) & Visceral AT & nd & ns & 12 pairs of male twins \\
\hline Herranz et al. (63) & WHR & nd & -0.17 & 34 \\
\hline Haffner et al. (67) & WHR & nd & -0.07 & 87 Finnish \\
\hline Haffner et al. (64-66) & WHR & nd & $-0.29 *$ & 178 Mexican-American non-Hispanic whites \\
\hline Ravaglia et al. (59) & WHR & nd & $+0.47^{*}$ & 36 older \\
\hline Abbassi et al. (58) & WHR & nd & -0.16 & 144 older \\
\hline Field et al. (55) & WHR & $-0.11^{*}$ & $-0.10^{*}$ & 1241 \\
\hline \multirow[t]{2}{*}{ Couillard et al. (56) } & WHR & $-0.37^{\star}$ & $-0.32^{*}$ & 217 \\
\hline & Visceral AT & $-0.32^{*}$ & $-0.36^{\star}$ & \\
\hline \multirow[t]{2}{*}{ Tchernof et al. (57) } & WHR & $-0.38^{\star}$ & $+0.64^{\star} \dagger$ & 80 \\
\hline & Visceral AT & $-0.33^{\star}$ & $+0.48^{*} \dagger$ & \\
\hline
\end{tabular}

*Statistically significant association; nd, not determined; ns, non-significant correlation coefficient not provided in the paper; tnot provided in the original paper; WHR, waist-to-hip ratio; visceral AT, visceral adipose tissue area measured by computed tomography.

(76, 78-82). The enzymes responsible for the inactivation of androgens/estrogens are also present in adipose tissue (83), thereby modulating the intracellular levels of active steroids. The intracrine conversion of DHEA to either androgens or estrogens in a site-specific fashion could affect adipocyte physiology and modulate adipose tissue accumulation and mobilization.

\section{Insulin resistance and hyperinsulinemia}

A series of studies have shown that insulin may act as a down-regulator of DHEA biosynthesis in the adrenal gland by inhibiting the activity of the enzyme 17,20lyase (84-87). This effect of insulin on DHEA secretion has been observed in studies where experimental hyperinsulinemia was induced (85-87). In this regard, it has been proposed that reduced DHEA may mediate the relationship with an increased risk of cardiovascular disease through a diminished inhibition of fibroblast growth and differentiation, alterations in the plasma lipid profile and through a diminished inhibition of platelet aggregation (88). It has also been shown that insulin may increase the metabolic clearance of DHEA (89), and studies by our group have demonstrated that hyperinsulinemia induced during DHEA infusion stimulated DHEA fatty acid esterification through the action of plasma lecithin: cholesterol acyltrasferase (90). On the other hand, DHEA-S may have direct effects on insulin sensitivity by increasing insulin binding to its own receptor (91).
The above-mentioned data suggest the possibility that reduced DHEA may directly contribute to insulin resistance. DHEA may also be related to insulin resistance and hyperinsulinemia through its association with obesity. In agreement with this possibility, we have observed that statistical control for differences in adiposity and abdominal fat accumulation eliminated the association between DHEA and glucose tolerance in men (92). These results suggest that adiposity may mediate a significant portion of the association between DHEA and hyperinsulinemia/insulin resistance. Further studies are needed, however, to help identify the primary factor(s) responsible for these complex inter-relationships.

\section{Plasma lipids and lipoproteins}

A number of cross-sectional studies have examined the relationships between endogenous DHEA or DHEA-S and plasma levels of lipids and lipoproteins (58, 64, 93-97). Results from these studies have been somewhat inconsistent. The most consistent association has been found between plasma DHEA-S and triglyceride levels. Indeed, three studies $(59,64,94)$ have reported a significant negative relationship between these two variables. Some studies have also found that elevated plasma DHEA or DHEA-S levels may be related to a favorable plasma lipid-lipoprotein profile through positive associations with the HDL-cholesterol concentration $(58,64)$, and negative associations with 
total cholesterol (95). A number of studies, however, reported no significant relationships (64, 93, 94). Again, several variables such as differences in age as well as the degree of obesity and abdominal fat accumulation may have represented important confounding factors in the evaluation of these associations. Accordingly, we have found that the associations between plasma DHEA and variables of the lipid-lipoprotein profile could be explained to a large extent by concomitant variations in adiposity and abdominal body fat accumulation (95). Interestingly, at least in men, the associations of DHEA with variables of the lipid profile are similar to those of testosterone with these variables (95); namely, elevated plasma androgens appear to be related to a favorable plasma lipidlipoprotein profile in men (98), which supports the notion that DHEA may be related to the lipid profile through its conversion to androgenic steroids.

\section{Cardiovascular disease}

A number of prospective studies comparing serum DHEA or DHEA-S levels in cardiovascular disease cases versus controls have been published (summarized in Table 3). Most of these studies were nested case-control designs, which provide useful information on risk factors for various cardiovascular disease endpoints, but generally have the caveat of overestimating the relative risk associated with a given factor. Results have been inconclusive in both men and women (Table 3). In women, one study found lower DHEA-S levels in ischemic heart disease cases compared with controls (99), whereas this association was not found in the other study (100). In men, results are even more contradictory, as one study found lower DHEA-S levels in myocardial infarction cases compared with controls (101), while another smaller size study actually found increased DHEA-S in myocardial infarction cases (102). Two other studies did not find a significant association $(103,104)$.

Epidemiological prospective population studies have examined the relationship of endogenous serum DHEA-S levels with cardiovascular disease mortality rates. These studies are summarized in Tables 4 and 5. The studies performed in women (Table 4) are very consistent in demonstrating that there is no relationship between plasma DHEA-S levels and mortality from cardiovascular disease or other causes. Indeed, no significant association was found in all seven population studies performed to date (105112). A trend for higher mortality rates in women with elevated DHEA-S was found in the study by Barrett-Connor \& Khaw Gruen (110). However, no $P$ value was provided in this short communication, and a later examination of the same cohort, when more women were included $(111,112)$, generated a non-significant relationship.

Prospective population studies on DHEA-S and mortality rates in men are summarized in Table 5. As opposed to the statistically non-significant studies in women, most studies in men (five out of seven) found that elevated levels of DHEA-S were associated with lower mortality rates, either from cardiovascular disease or any other cause (8, 106, 108, 109, 112), while the two others generated non-significant results. Odds ratios calculated for the risk increase associated with low DHEA-S values ranged from 1.17 to 3.3. The highest value was obtained by Barrett-Connor et al. (8) in the first analysis of the Rancho Bernardo population. A later analysis of the same population demonstrating a much lower odds ratio (1.17) revealed that the risk associated with low DHEA-S may have

Table 3 Prospective nested case-control studies on DHEA, DHEA-S and cardiovascular disease endpoints.

\begin{tabular}{|c|c|c|c|c|c|}
\hline Studies & $\begin{array}{c}\text { Follow-up } \\
\text { duration (years) }\end{array}$ & CVD endpoint & Population & $\begin{array}{l}\text { Hormone } \\
\text { measured }\end{array}$ & Result \\
\hline \multicolumn{6}{|l|}{ Women } \\
\hline Hill Golden et al. (100) & 3 & $\begin{array}{l}\text { Carotid } \\
\text { IMT }\end{array}$ & $\begin{array}{l}182 \text { cases } \\
182 \text { controls }\end{array}$ & DHEA-S & ns \\
\hline Haffner et al. (99)* & 5 & $\begin{array}{l}\text { IHD } \\
\text { mortality }\end{array}$ & $\begin{array}{l}40 \text { cases } \\
80 \text { controls }\end{array}$ & DHEA-S & DHEA-S lower in cases \\
\hline \multicolumn{6}{|c|}{ 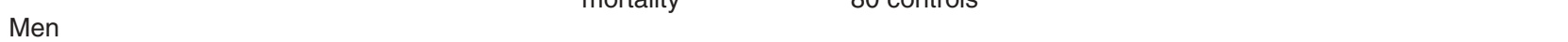 } \\
\hline Hautanen et al. (102) & 4 & Non-fatal MI, death & $\begin{array}{l}62 \text { cases } \\
97 \text { controls }\end{array}$ & $\begin{array}{l}\text { DHEA } \\
\text { DHEA-S }\end{array}$ & DHEA-S higher in cases \\
\hline Newcomer et al. (103) & 5 & Fatal, non-fatal MI & $\begin{array}{l}196 \text { cases } \\
196 \text { controls }\end{array}$ & DHEA-S & ns \\
\hline Haffner et al. (99)* & 5 & $\begin{array}{l}\text { IHD } \\
\text { mortality }\end{array}$ & $\begin{array}{l}41 \text { cases } \\
82 \text { controls }\end{array}$ & DHEA-S & ns \\
\hline Contoreggi et al. (104) & 9.5 & $\begin{array}{l}\mathrm{MI} \text {, angina } \\
\mathrm{ECG}^{* *}\end{array}$ & $\begin{array}{l}46 \text { cases } \\
124 \text { controls }\end{array}$ & DHEA-S & 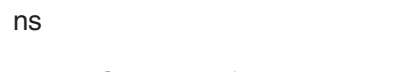 \\
\hline LaCroix et al. (101) & 18 & Fatal, non-fatal MI & $\begin{array}{l}238 \text { cases } \\
476 \text { controls }\end{array}$ & DHEA-S & DHEA-S lower in fatal MI cases \\
\hline
\end{tabular}

CVD, cardiovascular disease; IHD, ischemic heart disease; IMT, intimal media thickness measured by B-mode ultrasound; MI, myocardial infarction; ECG, electrocardiography; *this study was performed in diabetic patients; **in this study, cases included men with actue events (MI or death), angina pectoris or combinations of resting and/or exercise ECG alterations; ns, not significantly different among cases and controls. 
Table 4 Prospective population studies on DHEA-S and mortality in women.

\begin{tabular}{|c|c|c|c|c|c|}
\hline Studies & $\begin{array}{c}\text { Follow-up } \\
\text { duration (years) }\end{array}$ & Outcome & Population & $\begin{array}{l}\text { Hormone } \\
\text { measured }\end{array}$ & $\begin{array}{c}\text { Result } \\
\text { (elevated DHEA-S =) }\end{array}$ \\
\hline Legrain et al. (105) & 3 & All- cause mortality & $\begin{array}{l}81 \text { (82.9 years) in } \\
\text { long-term hospital care }\end{array}$ & DHEA-S & ns \\
\hline Berr et al. (106) & 4 & All-cause mortality & $\begin{array}{l}356 \text { (>65 years) } \\
\text { PAQUID study }\end{array}$ & DHEA-S & ns \\
\hline Tilvis et al. (107) & 5 & $\begin{array}{l}\text { All-cause and } \\
\text { CVD mortality }\end{array}$ & $\begin{array}{l}421(75-85 \text { years }) \\
\text { Helsinki aging study }\end{array}$ & DHEA-S & ns \\
\hline Trivedi \& Khaw (108) & 7.4 & $\begin{array}{l}\text { All-cause and } \\
\text { CVD mortality }\end{array}$ & $\begin{array}{l}1171 \text { (65-76 years) } \\
\text { CGPH study }\end{array}$ & DHEA-S & ns \\
\hline Mazat et al. (109) & 8 & All-cause mortality & $\begin{array}{l}171 \text { (>65 years) } \\
\text { PAQUID study }\end{array}$ & DHEA-S & ns \\
\hline $\begin{array}{l}\text { Barrett-Connor \& } \\
\text { Khaw (110) }\end{array}$ & 12 & $\begin{array}{l}\text { All-cause and } \\
\text { CVD mortality }\end{array}$ & $\begin{array}{l}289 \text { (60-79 years) } \\
\text { Rancho Bernardo }\end{array}$ & DHEA-S & $\begin{array}{l}\text { Trend for higher all-cause } \\
\text { or CVD mortality rates* }\end{array}$ \\
\hline $\begin{array}{l}\text { Barrett-Connor \& } \\
\text { Goodman-Gruen } \\
(111,112)\end{array}$ & 19 & $\begin{array}{l}\text { All-cause, CVD and } \\
\text { IHD mortality }\end{array}$ & $\begin{array}{l}942 \text { (65.2 years) } \\
\text { Rancho Bernardo }\end{array}$ & DHEA-S & ns \\
\hline
\end{tabular}

CVD, cardiovascular disease; IHD, ischemic heart disease; ns, not significantly related to outcome; CGPH, Cambridge General Practice Health Study; PAQUID, Personnes Agées Quid Study; ${ }^{\star} P$ values or confidence intervals not provided in this study.

Table 5 Prospective population studies on DHEA-S and mortality in men.

\begin{tabular}{|c|c|c|c|c|c|}
\hline Studies & $\begin{array}{l}\text { Follow-up } \\
\text { duration (years) }\end{array}$ & Outcome & Population & $\begin{array}{l}\text { Hormone } \\
\text { measured }\end{array}$ & $\begin{array}{c}\text { Result } \\
\text { (elevated DHEA-S =) }\end{array}$ \\
\hline Legrain et al. (105) & 3 & All-cause mortality & $\begin{array}{l}13 \text { (82.9 years) in long-term } \\
\text { hospital care }\end{array}$ & DHEA-S & ns \\
\hline Berr et al. (106) & 4 & All-cause mortality & $\begin{array}{l}266 \text { men (>65 years) } \\
\text { PAQUID study }\end{array}$ & DHEA-S & Lower mortality rates \\
\hline Tilvis et al. (107) & 5 & $\begin{array}{l}\text { All-cause and } \\
\text { CVD mortality }\end{array}$ & $\begin{array}{c}150 \text { men ( } 75-85 \text { years) } \\
\text { Helsinki aging study }\end{array}$ & DHEA-S & ns \\
\hline Trivedi \& Khaw (108) & 7.4 & $\begin{array}{l}\text { All-cause and } \\
\text { CVD mortality }\end{array}$ & $\begin{array}{l}963 \text { men (65-76 years) } \\
\text { CGPH study }\end{array}$ & DHEA-S & $\begin{array}{l}\text { Lower all-cause or } \\
\text { CVD mortality rates }\end{array}$ \\
\hline Mazat et al. (109) & 8 & All-cause mortality & $\begin{array}{l}119 \text { men (>65 years) } \\
\text { PAQUID study }\end{array}$ & DHEA-S & Lower mortality rates \\
\hline Barrett-Connor et al. (8) & 12 & $\begin{array}{l}\text { All-cause and } \\
\text { CVD mortality }\end{array}$ & $\begin{array}{l}242 \text { men (50-79 years) } \\
\text { Rancho Bernardo }\end{array}$ & DHEA-S & $\begin{array}{l}\text { Lower all-cause or } \\
\text { CVD mortality rates }\end{array}$ \\
\hline $\begin{array}{l}\text { Barrett-Connor \& } \\
\text { Goodman-Gruen (112) }\end{array}$ & 19 & $\begin{array}{l}\text { All-cause, CVD and } \\
\text { IHD mortality }\end{array}$ & $\begin{array}{l}1029 \text { men ( } 60.4 \text { years) } \\
\text { Rancho Bernardo }\end{array}$ & DHEA-S & Lower CHD or IHD rates* \\
\hline
\end{tabular}

CVD, cardiovascular disease; IHD, ischemic heart disease; ns, not significantly related to outcome; CGPH, Cambridge General Practice Health Study; PAQUID, Personnes Agées Quid Study; *Association significant only when excluding deaths from other causes.

been overestimated in the first study (112). Thus, the available studies on mortality rates and serum DHEA$\mathrm{S}$ in men suggest that low DHEA-S values are associated with a moderate, though significant, increase in the relative risk of mortality (approximately 1.5 -fold) (108, 109, 112).

Several other longitudinal, cross-sectional and retrospective analyses have examined the relationship between DHEA-S levels and the presence or the extent of various aspects of cardiovascular disease. Several studies have identified plasma DHEA or DHEA-S as being cardioprotective (113-118). In both men and women, elevated DHEA-S levels were associated with retarded progression of atherosclerosis measured by coronary artery angiography (113), ultrasound carotid wall thickness (117) and pulse wave velocity aorta calcification (114). On the other hand, other groups did not confirm these findings using coronary angiography in two male samples $(119,120)$. Retrospective studies have examined whether myocardial infarction survivors were characterized by reduced DHEA-S levels compared with healthy controls $(115,116,118)$. Two of these studies demonstrated that DHEA-S levels were lower in myocardial infarction survivors compared with healthy controls $(115,116)$, while the third one found the opposite (116). A study by Jansson et al. (121) examined male and female myocardial infarction survivors over a 10-year follow-up period and found that although a low DHEA-S level was a predictor of cardiovascular mortality, the association was not independent of age (121). A recent large-scale, community based prospective study by Kiechl et al. (Bruneck study) (122) found no association between plasma DHEA-S and high resolution duplex ultrasound-measured 
carotid atherosclerosis progression after a 5-year follow-up. No correlation was found between atherosclerosis or intimal media thickness. Finally, a 6.5year prospective study on radiography-detected atherosclerosis progression (aortic calcification) in non-smoking men and women from the Rotterdam study found that although low DHEA-S levels tended to be associated with increased atherosclerosis progression, this relationship did not reach statistical significance (123).

The reasons for the numerous discrepancies among studies are unclear at the present time. It has been suggested that they may be due to the possible confounding effect of smoking on both DHEA-S and cardiovascular disease, or to differences in the analytical methods used or to the cardiovascular endpoint selected $(115,124)$, although some studies cited above have already avoided these caveats. It has also been hypothesized that differences may be attributable to population variability. For example, the prospective study by Mazat et al. (109), demonstrated that the relative risk of 8-year mortality associated with low DHEA$\mathrm{S}$ was 3.4 times higher in males under 70 years compared with older men (odds ratios of 6.5 versus 1.9 respectively), suggesting substantial heterogeneity in this population according to age (109). Adjustment for BMI in most studies may have attenuated the relationship of DHEA-S to cardiovascular disease endpoints. Finally, most studies have relied on a single measure of plasma DHEA-S performed several years before the disease events. Diurnal variations in the levels of this hormone and possible alterations in frozen samples over time may have had an impact on the associations observed (15).

In summary, data available on the potential role of DHEA as a predictor of cardiovascular disease indicate that plasma DHEA-S is not a predictor of cardiovascular disease outcome in women, and is a relatively weak one in men. Endogenous DHEA appears to be more closely associated with other cardiovascular disease risk factors such as insulin resistance or abdominal fat distribution. Accordingly, low DHEA has recently been suggested to represent a non-specific marker of poor health and lack of adaptive capacity to the diseases of aging (15).

\section{Exogenous DHEA}

Whether pharmacological DHEA treatment should be used to replace declining DHEA and DHEA-S levels in aging individuals has attracted much attention and debate $(12-14)$. Claims have been made that such treatment could have beneficial effects on a series of aging-related conditions or diseases. Intervention trials have the advantage of avoiding several caveats of epidemiological studies. However, possibly due to the small size of many of the studies performed, discrepancies in the effects of DHEA have been reported. Reviewing all of the potential effects of DHEA treatment is beyond the scope of the present article. The following section will focus on DHEA treatment versus cardiovascular disease risk factors and body fatness.

As summarized in Table 6, more than a dozen studies have examined the effects of DHEA treatment on the plasma lipid-lipoprotein profile $(6,11,125-137)$. These studies were performed in both men and women of various ages and health conditions, using various doses of oral or transdermal DHEA. Treatments lasted from 4 to 52 weeks and the number of patients in each study was relatively small (from 6 to 60 subjects), although most studies used randomized, double-blind designs. One study was performed in a large sample of men and women $(n=280)$ (138). A total of eight studies indicated no effect of DHEA replacement on plasma lipids. These studies were performed with dosage ranging from 25 to $1600 \mathrm{mg}$ /day oral DHEA and durations from 4 to 36 weeks $(127,129-131$, 134-137). Examining the effects of DHEA replacement in subjects with previously documented hypercholesterolemia did not lead to the finding of significant effects of the treatment in a 12-week randomized placebo-controlled study using $25 \mathrm{mg}$ /day oral DHEA (127). On the other hand, some studies reported significant effects of DHEA on blood lipids $(6,11,125,126,128,132$, 133). All the studies reporting significant effects of DHEA on lipid-lipoprotein levels found a slight but significant decrease in HDL-cholesterol levels, which appeared to occur mostly in women $(11,125,126$, $128,132,133)$. In most instances, this effect was paralleled by a reduction in total cholesterol $(125,126$, 133). One study reported a decrease in HDL-cholesterol and total cholesterol in healthy older men (132). The studies reporting significant effects of DHEA on blood lipids employed sample sizes that varied from 6 to 39 subjects, with oral doses varying from 25 to $1600 \mathrm{mg} /$ day, or 300-500 mg/day transdermal doses in one instance (125). The only study to find a significant favorable effect of DHEA on the lipid profile was the one published by Nestler et al. (6), in which total and LDL-cholesterol were decreased in men after 4 weeks of a $1600 \mathrm{mg} /$ day dose of DHEA (6).

With respect to changes in body composition and body fat distribution following DHEA treatment, ten studies reported no significant effect of oral DHEA treatment on anthropometric measures such as BMI or WHR or other measures of adiposity such as underwater weighing, dual energy X-ray absorptiometry and bioimpedance, with oral doses varying from 25 to $1600 \mathrm{mg} /$ day, and treatments lasting from 4 to 52 weeks $(11,126,128,130,134,136-140)$. On the other hand, four studies found a significant effect of DHEA on body composition or body fat distribution $(6,125,129,132)$. The study by Nestler et al. (6) reported a $31 \%$ decrease in underwater weighingmeasured percent body fat after only 4 weeks of DHEA treatment at $1600 \mathrm{mg} /$ day (6). However, these results were not repeated in obese or normal men 
Table 6 Studies on DHEA replacement, adiposity and plasma lipid levels.

\begin{tabular}{|c|c|c|c|c|c|c|}
\hline Studies & Design & $\begin{array}{l}\text { Duration } \\
\text { (weeks) }\end{array}$ & $\begin{array}{l}\text { Dose } \\
\text { (mg/day) }\end{array}$ & Population & $\begin{array}{l}\text { Effects on } \\
\text { adiposity }\end{array}$ & $\begin{array}{l}\text { Effects on } \\
\text { blood lipids }\end{array}$ \\
\hline Nestler et al. (6) & $\mathrm{dbRPC}$ & 4 & 1600 oral & 10 men healthy & $\downarrow F M$ & $\downarrow \mathrm{CHOL} \downarrow$ LDL-C \\
\hline Mortola \& Yen (126) & $\mathrm{dbRPC} *$ & 4 & 1600 oral & $\begin{array}{l}6 \text { women } \\
\text { postmenopausal }\end{array}$ & ns & $\downarrow \mathrm{CHOL} \downarrow \mathrm{HDL}-\mathrm{C}$ \\
\hline Welle et al. (140) & dbRPC* & 4 & 1600 oral & 8 men healthy & ns & $\mathrm{nr}$ \\
\hline Usiskin et al. (136) & Seq.Pla-DHEA & 4 & 1600 oral & 6 men obese & ns & $\mathrm{ns}$ \\
\hline Vogiatzi et al. (134) & $\mathrm{dbRPC}$ & 8 & 80 oral & $\begin{array}{l}3 \text { men/10 women } \\
\text { morbid obese }\end{array}$ & ns & ns \\
\hline Kawano et al. (127) & $\mathrm{dbRPC}$ & 12 & 25 oral & $\begin{array}{l}24 \text { men with } \\
\text { hypercholesterol }\end{array}$ & $\mathrm{nr}$ & ns \\
\hline Flynn et al. (132) & $\mathrm{dbRPC}^{*}$ & 12 & 100 oral & 39 men healthy & $\downarrow$ Body wt (trend) & $\downarrow \mathrm{CHOL} \downarrow$ HDL-C \\
\hline Barnhart et al. (135) & $\mathrm{dbRPC}$ & 12 & 50 oral & $\begin{array}{l}60 \text { women } \\
\text { perimenopausal }\end{array}$ & $\mathrm{nr}$ & ns \\
\hline Jedrzejuk et al. (137) & $\mathrm{dbRPC} *$ & 12 & 50 oral & 12 men healthy & ns & ns \\
\hline Callies et al. (139) & dbRPC* & 16 & 50 oral & $\begin{array}{l}24 \text { women adrenal } \\
\text { insufficiency }\end{array}$ & ns & $\mathrm{nr}$ \\
\hline Arlt et al. (130) & $\mathrm{dbRPC}{ }^{*}$ & 16 & 50 oral & 22 men healthy & ns & ns \\
\hline Arlt et al. (133) & $\mathrm{dbRPC}{ }^{*}$ & 16 & 50 oral & $\begin{array}{l}24 \text { women adrenal } \\
\text { insufficiency }\end{array}$ & $\mathrm{nr}$ & $\downarrow \mathrm{CHOL} \downarrow \mathrm{HDL}-\mathrm{C}$ \\
\hline Casson et al. (128) & $\mathrm{dbRPC}$ & 24 & 25 oral & $\begin{array}{l}13 \text { women } \\
\text { postmenopausal }\end{array}$ & ns & $\downarrow \mathrm{HDL}-\mathrm{C} \downarrow \mathrm{Apo}-\mathrm{A} 1$ \\
\hline Villareal et al. (129) & CT & 24 & 50 oral & $\begin{array}{l}10 \text { women/8 men } \\
10 \text { matched cont. }\end{array}$ & $\downarrow$ FM $\downarrow$ Trunk fat & ns \\
\hline Morales et al. (11) & $\mathrm{dbRPC} *$ & 24 & 50 oral & 13 men 17 women & ns & $\downarrow$ HDL-C (women) \\
\hline Lovas et al. (131) & $\mathrm{dbRPC}$ & 36 & 25 oral & $\begin{array}{l}39 \text { women } \\
\text { adrenal failure }\end{array}$ & $\mathrm{nr}$ & ns \\
\hline Percheron et al. (138) & $\mathrm{dbRPC}$ & 52 & 50 oral & 140 men 140 women & ns & $\mathrm{nr}$ \\
\hline Diamond et al. (125) & DHEA only & 52 & $\begin{array}{l}300-500 \\
\text { transderm }\end{array}$ & $\begin{array}{l}15 \text { women } \\
\text { postmenopausal }\end{array}$ & $\downarrow$ Skinfold thickness & $\downarrow \mathrm{CHOL} \downarrow$ HDL-C \\
\hline
\end{tabular}

dbRPC, double-blind randomized placebo-controlled; *cross-over design; Seq.Pla-DHEA, placebo and DHEA taken in sequence in that study (no washout); $\mathrm{CT}$, controlled-trial; matched cont., age- and sex-matched control subjects; FM, body fat mass; Body wt, body weight; CHOL, total cholesterol; HDL-C, HDL cholesterol; ns, no significant effect; nr, not reported.

following similar protocols $(136,140)$. The study by Flynn et al. (132) reported a trend for a decrease in body weight, with no changes in body composition after 12 weeks of $100 \mathrm{mg}$ /day oral DHEA in 39 healthy older men (132). The study by Diamond et al. (125) found a $9 \%$ reduction in fat mass as estimated by skinfold thickness, in a sample of postmenopausal women receiving 300-500 $\mathrm{mg} /$ day transdermal DHEA for 1 year. More recently, the study of Villareal and colleagues (129) examined the effects of a 24-week oral DHEA ( $50 \mathrm{mg} /$ day) treatment in men and women with low DHEA-S levels. This study demonstrated a clear and significant reduction in dual energy X-ray absorptiometry-measured total body fatness and trunk fat, as well as an increase in fat-free mass. The selection of patients with low values of DHEA may have been an important factor for the finding of significant effects on body composition and fat distribution in that study, although other studies performed in men with low DHEA-S or women with adrenal insufficiency found no effects of DHEA on body composition (130, 139). Finally, in the study by Kawano et al. (127), although no effect on the lipid profile or body fatness were observed, other cardiovascular disease-related outcomes such as endothelial function and insulin sensitivity were significantly improved in response to DHEA supplementation in this sample of 24 hypercholesterolemic men, which may be considered as a cardioprotective effect of DHEA (127).

Ebeling \& Koivisto (141) made the suggestion that the outcome of DHEA treatment may depend on the initial hormonal milieu. For example, in premenopausal women, potential androgenic actions of DHEA may be counterbalanced by high estrogen concentrations in these subjects. This most interesting hypothesis is consistent with the above-mentioned findings from Villareal et al. (129) in subjects with low DHEA$\mathrm{S}$ and, in our opinion, deserves further investigation. On the other hand, the same authors have suggested that, in men, estrogen-like effects of DHEA may explain the results of DHEA treatment studies (141). However, this last statement is not supported by current literature on sex hormones and cardiovascular disease risk factors. In fact, in men, elevated endogenous testosterone, rather than estradiol, has generally been associated with a favorable risk profile for cardiovascular disease including reduced obesity, lower abdominal and visceral fat accumulation, increased HDL-cholesterol, lower triglyceride levels and apolipoprotein B, as well as reduced insulin resistance $(57,92,95,98)$. High-dose androgen treatment in men (i.e. anabolic steroid treatment) has been reported to drastically alter the plasma lipoprotein profile in several studies (reviewed in 142). However, data on physiological 
testosterone replacement suggests that low-dose testosterone treatment may be favorable by reducing adiposity (especially visceral adiposity) and improving insulin sensitivity $(143-146)$. Thus, the protective effects of DHEA observed in the studies of Villareal et al. (129) and Nestler et al. (6) may be related to androgenic rather than estrogenic effects of DHEA.

In agreement with this suggestion, the reductions in HDL-cholesterol observed with DHEA treatment in some studies is believed to be the result of DHEA conversion to androgens $(128,129,133)$. These effects are possibly mediated through androgen-induced increases in the activity of hepatic lipase, a critical enzyme of HDL metabolism that appears to be regulated by both androgens and estrogens, or by an increased scavenger receptor B1-mediated uptake of HDL lipids (15). Interestingly, the moderate inhibitory effect on HDL-cholesterol levels reported in some DHEA studies $(11,125,126,128,132,132,133)$ is also consistent with the effects of low-dose testosterone replacement on blood lipids. As reviewed by Barrett-Connor (147) and Gruenewald \& Matsumoto (148), the effects of physiological testosterone treatment on HDL-cholesterol and other variables of the lipid profile in men appear to be neutral or non-significant.

A detailed study of the hormonal response to DHEA treatment (149) provides further support for the notion of an androgenic conversion of DHEA, at least in men. In that study (149), we showed that the plasma levels of glucuronide androgen metabolites mirror those of plasma DHEA following treatment and are, therefore, more sensitive and valid indicators of the androgenic milieu. On the other hand, plasma testosterone or estradiol concentrations were unaffected by this treatment in men. It was thus observed that DHEA was preferentially converted to androgens, most likely peripherally, providing each tissues with locally produced active androgens (149). Supporting the hypothesis of a predominantly peripheral conversion of DHEA to androgens is the highly variable response of plasma testosterone to DHEA treatment among studies. Some but not all demonstrated significant increases in plasma testosterone, suggesting variability in the capacity and availability of peripheral tissues, such as adipose tissue for example, for peripheral conversion.

Taken together, the available data demonstrate that the effects of DHEA on the plasma lipid-lipoprotein profile are at best modest, or usually non-significant. The fact that HDL-cholesterol levels decrease slightly following DHEA treatment in women $(11,125,126,133)$ may be of some concern, although these changes were not unanimous and were balanced by a concomitant decrease in total cholesterol in some studies (125, $126,133)$. In addition, the recent finding that the antiatherogenicity of HDLs may be explained by their kinetics and functionality rather than by plasma HDL-cholesterol levels per se raises questions on the negative impact of DHEA-induced or androgen-induced decreases in HDL-cholesterol levels (15, 150). Most studies on body composition and fat distribution failed to demonstrate significant effects of DHEA replacement, although one recent study in older subjects with low baseline DHEA-S values reported significant reductions after 6 months. Similar to any hormonal replacement, the results of DHEA intervention studies emphasize the need to evaluate the ratio of risk versus benefit of DHEA treatment, by considering both cardiovascular diseaseand non-cardiovascular disease-related outcomes. Given the high variability in the hormonal responses to DHEA treatment and the potentially important influence of the initial hormonal milieu (141), it is possible that specific patient populations will display different quantitative responses to DHEA.

\section{Conclusion}

In summary, elevated plasma levels of free DHEA are associated with reduced obesity and a smaller accumulation of abdominal body fat. The relationships between the sulfate ester DHEA-S and adiposity is less consistent, as contradictory results have been reported. Age differences in the populations studied may have confounded these associations. The mechanisms linking obesity and abdominal fat accumulation are unclear at the present time, but we suggest that the intracrine adipose tissue conversion of DHEA to active androgens, which are known to be involved in the direct regulation of adipocyte physiology, body fat accretion and regional fat distribution, may be a significant factor in these associations. Cross-sectional studies on the associations between DHEA, DHEA-S and plasma lipoproteins have demonstrated that elevated levels of these hormones may be beneficial, especially regarding triglyceride levels. On the other hand, serum DHEA-S is not a predictor of cardiovascular disease endpoints in women, and appears as a relatively weak one in men. It is suggested that adiposity and body fat distribution, which are associated both with plasma DHEA and cardiovascular disease risk, may play a predominant role in this relationship. DHEA intervention studies suggest that the effects of DHEA on serum lipids are, at best, modest or non-significant, and most studies reported no significant effects on body composition and body fat distribution.

Much debate has been generated about whether endogenous and exogenous DHEA should be considered as cardioprotective. The uncertainty on this important issue is most definitely related to striking discrepancies noted in the literature on this topic. Several studies may have been plagued by various methodological problems, such as low statistical power, unreliable analytical methods, confounding factors or other differences in the clinical endpoints or populations studied. As a consequence, the original reports 
demonstrating dramatic effects of either endogenous or exogenous DHEA on cardiovascular disease endpoints have never been replicated. We propose that the effects of DHEA on cardiovascular disease risk (either favorable or unfavorable) should be considered as much more modest than previously believed. More studies may help identify the factors that have contributed to the study variability in this field. On the other hand, the impact of DHEA on cardiovascular disease risk may vary in populations with different hormonal characteristics and different capacities to convert DHEA to active estrogens/androgens peripherally. Sub-populations of DHEA responders and non-responders may be identified in future experiments.

\section{Acknowledgements}

A $\mathrm{T}$ is the recipient of a New Investigator Scholarship and F L is a distinguished scientist at the Canadian Institutes of Health Research.

\section{References}

1 Labrie F. Intracrinology. Molecular and Cellular Endocrinology 199178 C113-C118.

2 Labrie F, Luu-The V, Labrie C, Bélanger A, Simard J, Lin SX et al. Endocrine and intracrine sources of androgens in women: inhibition of breast cancer and other roles of androgens and their precursor dehydroepiandrosterone. Endocrine Reviews 200324 152-182.

3 Bélanger A, Candas B, Dupont A, Cusan L, Diamond P, Gomez JL et al. Changes in serum concentrations of conjugated and unconjugated steroids in 40- to 80-year-old men. Journal of Clinical Endocrinology and Metabolism 199479 1086-1090.

4 Labrie F, Bélanger A, Cusan L, Gomez JL \& Candas B. Marked decline in serum concentrations of adrenal C19 sex steroid precursors and conjugated androgen metabolites during aging. Journal of Clinical Endocrinology and Metabolism $1997 \mathbf{8 2}$ 2396-2402.

5 Schriock ED, Buffington CK, Hubert GD, Kurtz BR, Kitabachi AE, Buster JE et al. Divergent correlations of circulating dehydroepiandrosterone sulfate and testosterone with insulin levels and insulin receptor binding. Clinical Endocrinology and Metabolism $1988661329-1331$.

6 Nestler JE, Barlascini CO, Clore JN \& Blackard WG. Dehydroepiandrosterone reduces serum low density lipoprotein levels and body fat but does not alter insulin sensitivity in normal men. Journal of Clinical Endocrinology and Metabolism 198866 57-61.

7 Macewen EG \& Kurzman ID. Obesity in the dog: role of the adrenal steroid dehydroepiandrosterone (DHEA). Journal of Nutrition 1991121 S51-S55.

8 Barrett-Connor E, Khaw KT \& Yen S. A prospective study of dehydroepiandrosterone sulfate, mortality, and cardiovascular disease. New England Journal of Medicine $19863151519-1524$.

9 Schwartz AG, Pashko L \& Whitcomb JM. Inhibition of tumor development by dehydroepiandrosterone and related steroids. Toxicologic Pathology 198614 357-362.

10 Casson PR, Andersen RN, Herrod HG, Stentz FB, Straughn AB, Abraham GE et al. Oral dehydroepiandrosterone in physiologic doses modulates immune function in postmenopausal women. American Journal of Obstetrics and Gynecology $1993 \mathbf{1 6 9}$ $1536-1539$.
11 Morales AJ, Nolan JJ, Nelson JC \& Yen SSC. Effects of replacement dose of dehydroepiandrosterone in men and women of advancing age. Journal of Clinical Endocrinology and Metabolism 1994 78 1360-1367.

12 Skolnick AA. Scientific verdict still out on DHEA. Journal of the American Medical Association 1996276 1365-1367.

13 Casson RP \& Buster JE. DHEA administration to humans: panacea or palaver? Seminars in Reproductive Endocrinology 199513 247-256.

14 Nippolst TB. Dehydroepiandrosterone supplements: bringing sense to sensational claims. Endocrine Practice $1992 \mathbb{4}$ 106-111.

15 Wu FC \& Von Eckardstein A. Androgens and coronary artery disease. Endocrine Reviews 200324 183-217.

16 Liu PY, Death AK \& Handelsman DJ. Androgens and cardiovascular disease. Endocrine Reviews 200324 313-340.

17 Muller M, van der Shouw YT, Thijssen JHH \& Grobbee DE. Endogenous sex hormones and cardiovascular disease in men. Journal of Clinical Endocrinology and Metabolism $2003 \mathbf{8 8}$ 5076-5086.

18 Kissebah AH \& Krakower GR. Regional adiposity and morbidity. Physiological Reviews 1994 74 761-811.

19 Sims EAH \& Berchtold P. Obesity and hypertension: mechanisms and implications for management. Journal of the American Medical Association $1982 \mathbf{2 4 7} 49-52$.

20 Bray GA. Complications of obesity. Annals of Internal Medicine $19851031052-1062$.

21 Garrison RJ, Kannel WB, Stokes J III \& Castelli WP. Incidence and precursors of hypertension in young adults: the Framingham offspring study. Preventive Medicine 198716 235-251.

22 Kissebah AH, Freedman DS \& Peiris AN. Health risks of obesity. Medical Clinics of North America 198973 111-138.

23 Bray GA, Davidson MB \& Drenick EJ. Obesity: a serious symptom. Annals of Internal Medicine 197277 797-805.

24 Barrett-Connor E. Obesity, atherosclerosis, and coronary artery disease. Annals of Internal Medicine 1985103 1010-1019.

25 Manson JE, Willet WC, Stampfer MJ, Colditz GA, Hunter DJ, Hankinson SE et al. Body weight and mortality among women. New England Journal of Medicine $1995333677-685$.

26 Birmignham CL, Muller JL, Palepu A, Spinelli JJ \& Anis AH. The cost of obesity in Canada. The Canadian Medical Association Journal $1999 \mathbf{1 6 0} 483-488$.

27 Flegal KM, Carroll MD, Kuczmarski RJ \& Johnson CL. Overweight and obesity in the United States: prevalence and trends, 19601994. International Journal of Obesity 199822 39-47.

28 Kenchaiah S, Evans JC, Levy D, Wilson PWF, Benjamin EJ, Larson MG et al. Obesity and the risk of heart failure. New England Journal of Medicine 2002347 305-313.

29 Misra A, Garg A, Abate N, Peshock RM, Stray-Gundersen J \& Grundy SM. Relationship of anterior and posterior subcutaneous abdominal fat to insulin sensitivity in nondiabetic men. Obesity Research 19975 93-99.

30 Després JP, Moorjani S, Lupien PJ, Tremblay A, Nadeau A \& Bouchard C. Regional distribution of body fat, plasma lipoproteins, and cardiovascular disease. Arteriosclerosis $1990 \quad \mathbf{1 0}$ 497-511.

31 Lapidus L, Bengtsson C, Larsson B, Pennert K, Rybo E \& Sjöström L. Distribution of adipose tissue and risk of cardiovascular disease and death: a 12 year follow up of participants in the population study of women in Gothenburg, Sweden. British Medical Journal $19842891261-1263$.

32 Larsson B, Svardsudd K, Welin L, Wilhemsen L, Björntorp P \& Tibblin G. Abdominal adipose tissue distribution, obesity and risk of cardiovascular disease and death: 13-year follow-up of participants in the study of men born in 1913. British Medical Journal 1984288 1401-1404.

33 Ohlson LO, Larsson B, Svardsudd K, Welin L, Eriksson H, Wilhemsen L et al. The influence of body fat distribution on the incidence of diabetes mellitus: 13.5 years of follow-up of 
the participants in the study of men born in 1913. Diabetes 1985 34 1055-1058.

34 Ducimetière P, Richard J \& Cambien F. The pattern of subcutaneous fat distribution in middle-aged men and the risk of coronary heart disease: the Paris prospective study. International Journal of Obesity $198610229-240$.

35 Donahue RP, Abbot RD, Bloom E, Reed DM \& Yano K. Central obesity and coronary heart disease in men. Lancet $1987 \mathbf{i}$ $821-824$.

36 Björntorp P. Hazards in subgroups of human obesity. European Journal of Clinical Investigation $198414239-241$.

37 Kissebah AH, Vydelingum N, Murray R, Evans DJ, Hartz AJ, Kalkhoff RK et al. Relation of body fat distribution to metabolic complications of obesity. Journal of Clinical Endocrinology and Metabolism $1982 \mathbf{5 4} 254-260$.

38 Folsom AR, Kaye SA, Sellers TA, Hong CP, Cerhan JR, Potter JD et al. Body fat distribution and 5-year risk of death in older women. Journal of the American Medical Association 1993269 $483-487$.

39 van der Kooy K, Leenen R, Seidell JC, Deurenberg P, Droop A \& Bakker CJ. Waist-hip ratio is a poor predictor of changes in visceral fat. American Journal of Clinical Nutrition $199357327-333$.

40 Sjöström L, Kvist H, Cederblad A \& Tylen U. Determination of total adipose tissue and body fat in women by computed tomography, 40K, and tritium. American Journal of Physiology 1986250 E736-E745.

41 Després JP, Prud'homme D, Pouliot MC, Tremblay A \& Bouchard C. Estimation of deep abdominal adipose-tissue accumulation from simple anthropometric measurements in men. American Journal of Clinical Nutrition 199154 471-477.

42 Ferland M, Després JP, Tremblay A, Pinault S, Nadeau A, Moorjani S et al Assessment of adipose tissue distribution by computed axial tomography in obese women: association with body density and anthropometric measurements. British Journal of Nutrition 198961 139-148.

43 Després JP, Moorjani S, Ferland M, Tremblay Y, Lupien PJ, Nadeau A et al Adipose tissue distribution and plasma lipoprotein levels in obese women: importance of intra-abdominal fat. Arteriosclerosis 1989 9 203-210.

44 Svendsen OL, Hassager C \& Christiansen C. Relationships and independence of body composition, sex hormones, fat distribution and other cardiovascular risk factors in overweight postmenopausal women. International Journal of Obesity 199317 459-463.

45 Williams MJ, Hunter GR, Kekes-Szabo T, Snyder S \& Treuth MS. Regional fat distribution in women and risk of cardiovascular disease. American Journal of Clinical Nutrition 199765 855-860.

46 Wing RR, Matthews KA, Kuller LH, Meilahn EN \& Plantinga P. Waist to hip ratio in middle-aged women: associations with behavioral and psychosocial factors and with changes in cardiovascular risk factors. Arteriosclerosis and Thrombosis 199111 $1250-1257$.

47 Campos H, Bailey SM, Gussak LS, Siles X, Ordovas JM \& Schaefer EJ. Relations of body habitus, fitness level, and cardiovascular risk factors including lipoproteins in a rural and urban Costa Rican population. Arteriosclerosis and Thrombosis $1991 \mathbf{1 1}$ 1077-1088.

48 Haarbo J, Hassager C, Schlemmer A \& Christiansen C. Influence of smoking, body fat distribution, and alcohol consumption on serum lipids, lipoproteins, and apolipoproteins in early postmenopausal women. Atherosclerosis $199084239-244$.

49 Després JP, Nadeau A, Tremblay A, Ferland M, Moorjani S, Lupien PJ et al. Role of deep abdominal fat in the association between regional adipose tissue distribution and glucose tolerance in obese women. Diabetes 198938 304-309.

50 Lemieux S, Prud'homme D, Nadeau A, Tremblay A, Bouchard C \& Després JP. Seven-year changes in body fat and visceral adipose tissue in women: associations with indexes of plasma glucoseinsulin homeostasis. Diabetes Care 199619 983-991.
51 Fujioka S, Matsuzawa Y, Tokunaga K, Kano Y, Kobatake T, Keno $\mathrm{Y}$ et al. Improvement of glucose and lipid metabolism associated with selective reduction of intra-abdominal visceral fat in premenopausal women with visceral fat obesity. International Journal of Obesity 199115 853-859.

52 Barrett-Connor E \& Ferrara A. Dehydroepiandrosterone, dehydroepiandrosterone sulfate, obesity, waist-hip ratio, and noninsulin-dependent diabetes in postmenopausal women: the Rancho Bernardo study. Journal of Clinical Endocrinology and Metabolism 199681 59-64.

53 de Pergola G, Zamboni M, Sciaraffia M, Turcato E, Pannacciulli N, Armellini F et al. Body fat accumulation is possibly responsible for lower dehydroepiandrosterone circulating levels in premenopausal obese women. International Journal of Obesity $1996201105-1110$.

54 de Pergola G, Giagulli VA, Garruti G, Cospite MR, Giorgino F, Cignarelli $\mathrm{M}$ et al. Low dehydroepiandrosterone circulating levels in premenopausal obese women with very high body mass index. Metabolism $199140187-190$.

55 Field AE, Colditz GA, Willett WC, Longcope C \& McKinlay JB. The relation of smoking, age, relative weight, and dietary intake to serum adrenal steroids, sex hormones, and sex hormone-binding globulin in middle-aged men. Journal of Clinical Endocrinology and Metabolism 1994 79 1310-1316.

56 Couillard C, Gagnon J, Bergeron J, Leon AS, Rao DC, Skinner JS et al. Contribution of body fatness and adipose tissue distribution to the age variation in plasma steroid hormone concentrations in men: the HERITAGE family study. Journal of Clinical Endocrinology and Metabolism $2000 \mathbf{8 5} 1026-1031$.

57 Tchernof A, Després JP, Bélanger A, Dupont A, Prud'homme D, Moorjani S et al Reduced testosterone and adrenal C19 steroid levels in obese men. Metabolism $1995 \mathbf{4 4} 513-519$.

58 Abbassi A, Duthie EH Jr, Sheldahl L, Wilson C, Sasse E, Rudman I et al. Association of dehydroepiandrosterone sulfate, body composition, and physical fitness in independent community-dwelling older men and women. Journal of the American Geriatric Society $1998 \mathbf{4 6} 263-273$.

59 Ravaglia G, Forti P, Maioli F, Boschi F, Bernardi M, Pratelli L et al. The relationship of dehydroepiandrosterone sulfate (DHEAS) to endocrine-metabolic parameters and functional status in the oldest-old. Results from an Italian study on healthy free-living over-ninety-year-olds. Journal of Clinical Endocrinology and Metabolism 199681 1173-1178.

60 Vermeulen A, Kaufman JM \& Giagulli VA. Influence of some biological indexes on sex hormone-binding globulin and androgen levels in aging or obese males. Journal of Clinical Endocrinology and Metabolism $1996 \mathbf{8 1} 1821-1826$.

61 Pritchard J, Després JP, Gagnon J, Tchernof A, Nadeau A, Tremblay A et al. Plasma adrenal, gonadal and conjugated steroids before and after long term overfeeding in identical twins. Journal of Clinical Endocrinology and Metabolism $1998 \mathbf{8 3} 3277$-3284.

62 Vettor R, de Pergola G, Pagano C, Englaro P, Laudadio E, Giorgino $\mathrm{F}$ et al. Gender differences in serum leptin in obese people: relationships with testosterone, body fat distribution and insulin sensitivity. European Journal of Clinical Investigation 199727 1016-1024.

63 Herranz L, Megia A, Grande C, Gonzalez Gancedo P \& Pallardo F. Dehydroepiandrosterone sulphate, body fat distribution and insulin in obese men. International Journal of Obesity 199519 57-60.

64 Haffner SM, Mykkänen L, Valdez RA \& Katz MS. Relationship of sex hormones to lipids and lipoproteins in nondiabetic men. Journal of Clinical Endocrinology and Metabolism $1993 \quad 77$ 1610-1615.

65 Haffner SM, Valdez RA, Stern MP \& Katz MS. Obesity, body fat distribution and sex hormones in men. International Journal of Obesity 199317 643-649.

66 Haffner SM, Valdez RA, Mykkänen L, Stern MP \& Katz MS. Decreased testosterone and dehydroepiandrosterone sulfate concentrations are associated with increased insulin and glucose 
concentrations in nondiabetic men. Metabolism $1994 \mathbf{4 3}$ 599-603.

67 Haffner SM, Karhapaa P, Mykkänen L \& Laakso M. Insulin resistance, body fat distribution, and sex hormones in men. Diabetes $199443212-219$.

68 de Pergola G, Triggiani V, Giorgino F, Cospite MR, Garruti G, Cignarelli $\mathrm{M}$ et al. The free testosterone to dehydroepiandrosterone sulphate molar ratio as a marker of visceral fat accumulation in premenopausal obese women. International Journal of Obesity 199418 659-664.

69 De Simone M, Verrotti A, Lughetti L, Palumbo M, Farello G Di Cesare E et al. Increased visceral adipose tissue is associated with increased circulating insulin and decreased sex hormone binding globulin levels in massively obese adolescent girls. Journal of Endocrinological Investigation 200124 438-444.

70 Williams DP, Boyden TW, Pamenter RW, Lohman TG \& Going SB. Relationship of body fat percentage and fat distribution with dehydroepiandrosterone sulfate in premenopausal females. Journal of Clinical Endocrinology and Metabolism 199377 80-85.

71 Hautanen A, Mänttäri M, Kupari M, Sarna S, Manninen V, Frick MH et al. Cigarette smoking is associated with elevated adrenal androgen response to adrenocorticotropin. Journal of Steroid Biochemistry and Molecular Biology 199346 245-251.

72 Salvini S, Stampfer MJ, Barbieri RL \& Hennekens CH. Effects of age, smoking and vitamins on plasma DHEAS levels: a cross-sectional study in men. Journal of Clinical Endocrinology and Metabolism $1992 \mathbf{7 4}$ 139-143.

73 Evans DJ, Hoffmann RG, Kalkhoff RK \& Kissebah AH. Relationship of androgenic activity to body fat topography, fat cell morphology, and metabolic aberrations in premenopausal women. Journal of Clinical Endocrinology and Metabolism 1983 $57304-310$.

74 Ivandic A, Prpic-Krizevac I, Sucic M \& Juric M. Hyperinsulinemia and sex hormones in healthy premenopausal women: relative contribution of obesity, obesity type, and duration of obesity. Metabolism 199847 13-19.

75 Gordon GB, Newitt JA, Shantz LM, Weng DE \& Talalay P. Inhibition of the conversion of 3T3 fibroblast clones to adipocytes by dehydroepiandrosterone and related anticarcinogenic steroids. Cancer Research 198646 3389-3395.

76 Deslypere JP, Verdonck L \& Vermeulen A. Fat tissue: a steroid reservoir and site of steroid metabolism. Journal of Clinical Endocrinology and Metabolism $198561564-570$.

77 Fehér T \& Bodrogi L. A comparative study of steroid concentrations in human adipose tissue and the peripheral circulation. Clinica et Chimica Acta $1982 \mathbf{1 2 6} 135-141$.

78 Labrie F, Simard J, Luu-The V, Trudel C, Martel C, Labrie C et al. Expression of $3 \beta$-hydroxysteroid dehydrogenase/delta5-delta4

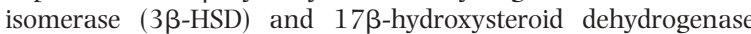
(17 $\beta$-HSD) in adipose tissue. International Journal of Obesity $19911591-99$.

79 Simpson ER, Merrill JC, Hollub AJ, Graham-Lorence S \& Mendelson CR. Regulation of estrogen biosynthesis by human adipose cells. Endocrine Reviews 198910 136-148.

80 Price TM \& O'Brien SN. Determination of estrogen receptor messenger ribonucleic acid (mRNA) and cytochrome P450 aromatase mRNA levels in adipocytes and adipose stromal cells by competitive polymerase chain reaction amplification. Journal of Clinical Endocrinology and Metabolism $1993 \mathbf{7 7}$ $1041-1045$.

81 Yang K, Khalil MW, Strutt BJ \& Killinger DW. 11ß-Hydroxysteroid dehydrogenase 1 activity and gene expression in human adipose stromal cells: effects on aromatase activity. Journal of Steroid Biochemistry and Molecular Biology $1997 \mathbf{6 0}$ 247-253.

82 Bélanger C, Luu-The V, Dupont P \& Tchernof A. Adipose tissue intracrinology: potential importance of local androgen/estrogen metabolism in the regulation of adiposity. Hormone and Metabolic Research 200234 737-745.
83 Tchernof A, Lévesque E, Beaulieu M, Couture P, Després JP, Hum DW et al. Expression of the androgen metabolizing enzyme UGT2B15 in adipose tissue and relative expression measurement using a competitive RT-PCR method. Clinical Endocrinology $199950637-642$.

84 Nestler JE, McClanahan MA, Clore JN \& Blackard WG. Insulin inhibits adrenal 17,20-lyase activity in man. Journal of Clinical Endocrinology and Metabolism 199274 362-367.

85 Nestler JE, Usiskin KS, Barlascini CO, Welty DF, Clore JN \& Blackard WG. Suppression of serum dehydroepiandrosterone sulfate levels by insulin: an evaluation of possible mechanisms. Journal of Clinical Endocrinology and Metabolism 198969 1040-1046.

86 Smith S, Ravnikar VA \& Barbieri RL. Androgen and insulin response to an oral glucose challenge in hyperandrogenic women. Fertility and Sterility $1987 \mathbf{4 8} 72-77$.

87 Falcone T, Finegood DT, Fantus IG \& Morris D. Androgen response to endogenous insulin secretion during the frequently sampled intravenous glucose tolerance test in normal and hyperandrogenic women. Journal of Clinical Endocrinology and Metabolism 199071 1653-1657.

88 Nestler JE, Clore JN \& Blackard WG. Dehydroepiandrosterone: the 'missing link' between hyperinsulinemia and atherosclerosis? FASEB Journal 19926 3073-3075.

89 Nestler JE \& Kahwash Z. Sex-specific action of insulin to acutely increase the metabolic clearance rate of dehydroepiandrosterone in humans. Journal of Endocrinological Investigation 199494 1484-1489.

90 Lavallée B, Provost PR, Nestler JE, Kahwash Z \& Bélanger A. Effect of insulin on serum levels of dehydroepiandrosterone metabolites in men. Clinical Endocrinology 1997 46 93-100.

91 Buffington CK, Givens JR \& Kitabchi AE. Opposing actions of dehydroepiandrosterone and testosterone on insulin sensitivity. In vivo and in vitro studies of hyperandrogenic females. Diabetes $199140693-700$.

92 Tchernof A, Després JP, Dupont A, Bélanger A, Nadeau A, Prud'homme D et al. Relation of steroid hormones to glucose tolerance and plasma insulin levels in men. Diabetes Care 199518 292-299.

93 Haffner SM, Newcomb PA, Marcus PM, Klein BE \& Klein R. Relation of sex hormones and dehydroepiandrosterone sulfate (DHEA-SO $\mathrm{S}_{4}$ ) to cardiovascular risk factors in postmenopausal women. American Journal of Epidemiology $1995142925-934$.

94 Barrett-Connor E. Lower endogenous androgen levels and dyslipidemia in men with non-insulin-dependent diabetes mellitus. Annals of Internal Medicine 1992117 807-811.

95 Tchernof A, Labrie F, Bélanger A, Bouchard C, Prud'homme D, Moorjani $S$ et al. Relationships between endogenous steroid hormone, sex hormone-binding globulin and lipoprotein levels in men: contribution of visceral obesity, insulin levels and other metabolic variables. Atherosclerosis $1997133235-244$.

96 Haffner SM, Laakso M, Miettinen H, Mykkänen L, Karhapaa P \& Rainwater DL. Low levels of sex-hormone-binding globulin and testosterone are associated with smaller, denser low density lipoprotein in normoglycemic men. Journal of Clinical Endocrinology and Metabolism 199681 3697-3701.

97 Rebuffé-Scrive M, Krotkiewski M, Elfverson J \& Björntorp P. Muscle and adipose tissue morphology and metabolism in Cushing's syndrome. Journal of Clinical Endocrinology and Metabolism $1988 \mathbf{6 7} 1122-1128$.

98 Tchernof A \& Després JP. Sex steroid hormones, sex hormonebinding globulin, and obesity in men and women. Hormone and Metabolic Research 200032 526-536.

99 Haffner SM, Moss SE, Klein BE \& Klein R. Sex hormones and DHEA-SO $\mathrm{S}_{4}$ in relation to ischemic heart disease mortality in diabetic subjects. The Wisconsin epidemiologic study of diabetic retinopathy. Diabetes Care 199619 1045-1050.

100 Hill Golden S, Maguire A, Ding J, Crouse JR, Cauley JA, Zacur H et al. Endogenous postmenopausal hormones and carotid atherosclerosis: a case-control study of the atherosclerosis risk in 
communities cohort. American Journal of Epidemiology $2002 \mathbf{1 5 5}$ 437-445.

101 LaCroix AZ, Yano K \& Reed DM. Dehydroepiandrosterone sulfate, incidence of myocardial infarction, and extent of atherosclerosis in men. Circulation 199286 1529-1535.

102 Hautanen A, Manttari M, Manninen V, Tenkanen L, Huttunen JK, Frick MH et al. Adrenal androgens and testosterone as coronary risk factors in the Helsinki heart study. Atherosclerosis 1994 105 191-200.

103 Newcomer LM, Manson JE, Barbieri RL, Hennekens CH \& Stampfer MJ. Dehydroepiandrosterone sulfate and the risk of myocardial infarction in US male physicians: a prospective study. American Journal of Epidemiology 1994140 870-875.

104 Contoreggi CS, Blackman MR, Andres R, Muller DC, Lakatta EG, Fleg JL et al. Plasma levels of estradiol, testosterone, and DHEAS do not predict risk of coronary artery disease in men. Journal of Andrology 199011 460-470.

105 Legrain S, Berr C, Frenoy N, Gourlet V, Debuire B \& Baulieu EE. Dehydroepiandrosterone sulfate in a long-term care aged population. Gerontology $1995 \mathbf{4 1} 343-351$.

106 Beer C, Lafont S, Debuire B, Dartigues JF \& Beaulieu EE. Relationships of dehydroepiandrosterone sulfate in the elderly with functional, psychological, and mental status, and shortterm mortality: a French community-based study. PNAS 1996 93 13410-13415.

107 Tilvis RS, Kähönen M \& Härkönen M. Dehydroepiandrosterone sulfate, diseases and mortality in a general aged population. Aging Clinical and Experimental Research 199911 30-34.

108 Trivedi DP \& Khaw KT. Dehydroepiandrosterone sulfate and mortality in elderly men and women. Journal of Clinical Endocrinology and Metabolism $2001 \mathbf{8 6} 4171-4177$.

109 Mazat L, Lafont S, Beer C, Debuire B, Tessier JF \& Dartigues JF. Prospective measurements of dehydroepiandrosterone sulfate in a cohort of elderly subjects: relationship to gender, subjective health, smoking habits, and 10-year mortality. PNAS 200198 8145-8150.

110 Barrett-Connor E \& Khaw KT. Absence of an inverse relation of dehydroepiandrosterone sulfate with cardiovascular mortality in postmenopausal women. New England Journal of Medicine 1987 317711.

111 Barrett-Connor E \& Goodman-Gruen D. Dehydroepiandrosterone sulfate does not predict cardiovascular death in postmenopausal women. The Rancho Bernardo study. Circulation 199591 1757-1760.

112 Barrett-Connor E \& Goodman-Gruen D. The epidemiology of DHEAS and cardiovascular disease. Annals of the New York Academy of Sciences $1995 \mathbf{7 7 4}$ 259-270.

113 Herrington DM. Dehydroepiandrosterone and coronary atherosclerosis. Annals of the New York Academy of Sciences 1995774 $271-280$.

114 Ishihara F, Hiramatsu K, Shigematsu S, Aizawa T, Niwa A, Takasu $\mathrm{N}$ et al. Role of adrenal androgens in the development of arteriosclerosis as judged by pulse wave velocity and calcification of the aorta. Cardiology $1992 \mathbf{8 0} 332-338$.

115 Mitchell LE, Sprecher DL, Borecki IB, Rice T, Laskarzewski PM \& Rao DC. Evidence for an association between dehydroepiandrosterone sulfate and nonfatal, premature myocardial infarction in males. Circulation $19948989-93$.

116 Zumoff B, Troxler RG, O'Connor J, Rosenfeld RS, Kream J \& Levin J. Abnormal hormone levels in men with coronary artery disease. Arteriosclerosis 19822 58-67.

117 Bernini GP, Moretti A, Sgrò M, Argenio GF, Barlascini CO, Cristofani R et al. Influence of endogenous androgens on carotid wall in postmenopausal women. Menopause 2001 8 43-50.

118 Slowinska-Srzednicka J, Zgliczynski S, Ciswicka-Sznajderman M, Srzednicki M, Soszynski P, Biernacka M et al. Decreased plasma dehydroepiandrosterone sulfate and dihydroepiandrosterone concentrations in young men after myocardial infarction. Atherosclerosis 198979 197-203.
119 Hauner H, Stangl K, Burger K, Busch U, Blomer H \& Pfeiffer EF. Sex hormone concentrations in men with angiographically assessed coronary artery disease - relationship to obesity and body fat distribution. Klinische Wochenschrift $1991 \quad 69$ $664-668$.

120 Phillips GB, Pinkernell BH \& Jing TY. The association of hypotestosteronemia with coronary artery disease in men. Arteriosclerosis and Thrombosis $1994 \mathbf{1 4} 701-706$.

121 Jansson JH, Nilsson TK \& Johnson O. Von Willebrand factor, tissue plasminogen activator, and dehydroepiandrosterone sulphate predict cardiovascular death in a 10 year follow up of survivors of acute myocardial infarction. Heart $1998 \mathbf{8 0}$ $334-337$.

122 Kiechl S, Willeit J, Bonora E, Schwarz S \& Xu Q. No association between dehydroepiandrosterone sulfate and development of atherosclerosis in a prospective population study (Bruneck study). Arteriosclerosis, Thrombosis and Vascular Biology 2000 20 1094-1100.

123 Hak AE, Witteman JCM, de Jong FH, Geerlings MI, Hofman A \& Pols HAP. Low levels of endogenous androgens increase the risk of atherosclerosis in elderly men: the Rotterdam study. Journal of Clinical Endocrinology and Metabolism 2002 87 3632-3639.

124 Nafziger AN, Herrington DM \& Bush TL. Dehydroepiandrosterone and dehydroepiandrosterone sulfate: their relation to cardiovascular disease. Epidemiologic Reviews 199113 267-293.

125 Diamond P, Cusan L, Gomez JL, Bélanger A \& Labrie F. Metabolic effect of 12-month percutaneous dehydroepiandrosterone replacement therapy in postmenopausal women. Journal of Endocrinology $1996 \mathbf{1 5 0}$ S43-S50.

126 Mortola JF \& Yen SC. The effects of oral dehydroepiandrosterone on endocrine- metabolic parameters in postmenopausal women. Journal of Clinical Endocrinology and Metabolism $1990 \quad \mathbf{7 1}$ 696-704.

127 Kawano H, Yasue H, Kitagawa A, Hirai N, Yoshida T, Soejima H et al. Dehydroepiandrosterone supplementation improves endothelial function and insulin sensitivity in men. Journal of Clinical Endocrinology and Metabolism 200388 3190-3195.

128 Casson PR, Santoro N, Elkind-Hirsch K, Carson SA, Hornsby PJ, Abraham G et al. Postmenopausal dehydroepiandrosterone administration increases free insulin-like growth factor-I and decreases high-density lipoprotein: a six-month trial. Fertility and Sterility $1998 \mathbf{7 0} 107-110$.

129 Villareal DT, Holloszy JO \& Kohrt WM. Effects of DHEA replacement on bone mineral density and body composition in elderly women and men. Clinical Endocrinology 200053 561-568.

130 Arlt W, Callies F, Koehler I, van Vlijmen JC, Fassnacht M, Strasburger CJ et al. Dehydroepiandrosterone supplementation in healthy men with an age-related decline of dehydroepiandrosterone secretion. Journal of Clinical Endocrinology and Metabolism $2001864686-4692$.

131 Lovas K, Gebre-Medhin G, Trovik TS, Fougner KJ, Uhlving S, Nedrebo BG et al. Replacement of dehydroepiandrosterone in adrenal failure: no benefit for subjective health status and sexuality in a 9-month, randomized, parallel group clinical trial. Journal of Clinical Endocrinology and Metabolism $2003 \mathbf{8 8}$ 1112-1118.

132 Flynn MA, Weaver-Osterholtz D, Sharpe-Timms KL, Allen S \& Krause G. Dehydroepiandrosterone replacement in aging humans. Journal of Clinical Endocrinology and Metabolism 1999 $841527-1533$.

133 Arlt W, Callies F, van Vlijmen JC, Koehler I, Reincke M, Bidlingmaier $\mathrm{M}$ et al. Dehydroepiandrosterone replacement in women with adrenal insuficiency. New England Journal of Medicine 1999341 1013-1020.

134 Vogiatzi MG, Boeck MA, Vlachopapadopoulou E, El Rashid R \& New MI. Dehydroepiandrosterone in morbidly obese adolescents: effects on weight, body composition, lipids, and insulin resistance. Metabolism $1996451011-1015$.

135 Barnhart KT, Freeman E, Grisso JA, Rader DJ, Sammel M, Kapoor $\mathrm{S}$ et al. The effect of dehydroepiandrosterone 
supplementation to symptomatic perimenopausal women on serum endocrine profiles, lipid parameters, and health-related quality of life. Journal of Clinical Endocrinology and Metabolism $1999843896-3902$.

136 Usiskin KS, Butterworth S, Clore JN, Arad Y, Ginsberg HN, Blackard WG et al. Lack of effect of dehydroepiandrosterone in obese men. International Journal of Obesity $1990 \mathbf{1 4}$ 457-463.

137 Jedrzejuk D, Medras M, Milewicz A \& Demissie M. Dehydroepiandrosterone replacement in healthy men with age-related decline of DHEA-S: effects on fat distribution, insulin sensitivity and lipid metabolism. Aging Male 20036 151-156.

138 Percheron G, Hogrel JY, Denot-Ledunois S, Fayet G, Forette F, Baulieu EE et al. Effect of 1-year oral administration of dehydroepiandrosterone to 60- to 80-year-old individuals on muscle function and cross-sectional area: a double-blind placebocontrolled trial. Archives of Internal Medicine $2003 \mathbf{1 6 3}$ $720-727$.

139 Callies F, Fassnacht M, van Vlijmen JC, Koehler I, Huebler D, Seibel MJ et al. Dehydroepiandrosterone replacement in women with adrenal insufficiency: effects on body composition, serum leptin, bone turnover, and exercise capacity. Journal of Clinical Endocrinology and Metabolism 200186 1968-1972.

140 Welle S, Jozefowicz R \& Statt M. Failure of dehydroepiandrosterone to influence energy and protein metabolism in humans. Journal of Clinical Endocrinology and Metabolism $1990 \mathbf{7 1}$ $1259-1264$.

141 Ebeling P \& Koivisto VA. Physiological importance of dehydroepiandrosterone. Lancet 1994343 1479-1481.

142 Glazer G. Atherogenic effects of anabolic steroids on serum lipid levels. A literature review. Archives of Internal Medicine 1991 151 1925-1933.

143 Mårin P, Holmäng S, Jönsson L, Sjöström L, Kvist H, Holm G et al. The effects of testosterone treatment on body composition and metabolism in middle-aged and obese men. International Journal of Obesity $199216991-997$.
144 Mårin P, Odén B \& Björntorp P. Assimilation and mobilization of triglycerides in subcutaneous abdominal and femoral adipose tissue in vivo in men: effects of androgens. Journal of Clinical Endocrinology and Metabolism 199580 239-243.

145 Mårin P, Lönn L, Andersson B, Odén B, Olbe L, Bengtsson BA \& Björntorp P. Assimilation of triglycerides in subcutaneous and intraabdominal adipose tissues in vivo in men: effects of testosterone. Journal of Clinical Endocrinology and Metabolism $1996 \mathbf{8 1}$ 1018-1022.

146 Mårin P, Holmäng S, Gustafsson C, Jönsson L, Kvist H, Elander A et al. Androgen treatment of abdominally obese men. Obesity Research 19931 245-251.

147 Barrett-Connor EL. Testosterone and risk factors for cardiovascular disease in men. Diabète et Métabolisme 199521 156-161.

148 Gruenewald DA \& Matsumoto AM. Testosterone supplementation therapy for older men: potential benefits and risks. Journal of the American Geriatric Society $2003 \mathbf{5 1} 101-115$.

149 Labrie F, Bélanger A, Cusan L \& Candas B. Physiological changes in dehydroepiandrosterone are not reflected by serum levels of active androgens and estrogens but of their metabolites: intracrinology. Journal of Clinical Endocrinology and Metabolism $1997 \mathbf{8 2}$ 2403-2409.

150 Von Eckardstein A \& Assmann G. Prevention of coronary heart disease by raising high-density lipoprotein cholesterol? Current Opinion in Lipidology $2000 \mathbf{1 1} 627-637$.

151 Maccario M, Mazza E, Ramunni J, Oleandri SE, Procopio M, Gauna G \& Ghigo E. Relationships between dehydroepiandrosterone-sulphate and anthropometric, metabolic and hormonal variables in a large cohort of obese women. Clinical Endocrinology 199950 595-600.

Received 30 September 2003

Accepted 15 March 2004 